\title{
In vitro migration of cytotoxic T lymphocyte derived from a colon carcinoma patient is dependent on CCL2 and CCR2
}

Klara Berencsi', Pyapalli Rani', Tianqian Zhang ${ }^{1}$, Laura Gross ${ }^{1}$, Michael Mastrangelo², Neal J Meropol ${ }^{3,4}$, Dorothee Herlyn ${ }^{1}$ and Rajasekharan Somasundaram ${ }^{1 *}$

\begin{abstract}
Background: Infiltration of colorectal carcinomas (CRC) with T-cells has been associated with good prognosis. There are some indications that chemokines could be involved in T-cell infiltration of tumors. Selective modulation of chemokine activity at the tumor site could attract immune cells resulting in tumor growth inhibition. In mouse tumor model systems, gene therapy with chemokines or administration of antibody (Ab)-chemokine fusion proteins have provided potent immune mediated tumor rejection which was mediated by infiltrating $T$ cells at the tumor site. To develop such immunotherapeutic strategies for cancer patients, one must identify chemokines and their receptors involved in T-cell migration toward tumor cells.
\end{abstract}

Methods: To identify chemokine and chemokine receptors involved in T-cell migration toward CRC cells, we have used our previously published three-dimensional organotypic CRC culture system. Organotypic culture was initiated with a layer of fetal fibroblast cells mixed with collagen matrix in a 24 well tissue culture plate. A layer of CRC cells was placed on top of the fibroblast-collagen layer which was followed by a separating layer of fibroblasts in collagen matrix. Anti-CRC specific cytotoxic T lymphocytes (CTLS) mixed with fibroblasts in collagen matrix were placed on top of the separating layer. Excess chemokine ligand (CCL) or Abs to chemokine or chemokine receptor (CCR) were used in migration inhibition assays to identify the chemokine and the receptor involved in CTL migration.

Results: Inclusion of excess CCL2 in T-cell layer or Ab to CCL2 in separating layer of collagen fibroblasts blocked the migration of CTLs toward tumor cells and in turn significantly inhibited tumor cell apoptosis. Also, Ab to CCR2 in the separating layer of collagen and fibroblasts blocked the migration of CTLs toward tumor cells and subsequently inhibited tumor cell apoptosis. Expression of CCR2 in four additional CRC patients' lymphocytes isolated from infiltrating tumor tissues suggests their role in migration in other CRC patients.

Conclusions: Our data suggest that CCL2 secreted by tumor cells and CCR2 receptors on CTLs are involved in migration of CTLs towards tumor. Gene therapy of tumor cells with CCL2 or CCL2/anti-tumor Ab fusion proteins may attract CTLs that potentially could inhibit tumor growth.

\section{Background}

Chemokines play an important role in immune homeostasis and immune surveillance (reviewed in [1-3]). Studies have demonstrated that chemokines influence immune reactions by regulating trafficking of dendritic cells (DC) and lymphocytes [4]. In tumor bearing individuals, the

\footnotetext{
* Correspondence: Shyam@wistar.org

${ }^{1}$ The Wistar Institute, 3601 Spruce Street, Philadelphia, PA 19104, USA Full list of author information is available at the end of the article
}

role of chemokines is paradoxical. Chemokines produced by tumor cells are known to stimulate autocrine tumor growth, progression and metastasis [4-10]. In contrast, chemokines produced by tumor cells can also attract chemokine receptor (CCR)-positive leukocytes into the tumor area, potentially leading to tumor growth inhibition in vitro and in vivo [9,11-13]. In colorectal carcinoma (CRC) patients, T-cell infiltration has been shown to be associated with good prognosis (reviewed in [14]
Ciomed Central

() 2011 Berencsi et al; licensee BioMed Central Ltd. This is an Open Access article distributed under the terms of the Creative Commons Attribution License (http://creativecommons.org/licenses/by/2.0), which permits unrestricted use, distribution, and reproduction in any medium, provided the original work is properly cited. 
and [15-19]). In these studies, favorable prognosis was correlated with the presence of tumor cells secreting chemokines such as CCL5, CXCL10 and CXCL1 that played a role in recruitment of $\mathrm{CCR}^{+} / \mathrm{CXCR}^{+} \mathrm{T}$-helper $(\mathrm{Th}) 1$ cells or $\mathrm{CX} 3 \mathrm{CR} 1^{+}$, perforin ${ }^{+} /$granzyme $\mathrm{B}^{+} \mathrm{T}$ cells [17], [18]. Colorectal and pancreatic carcinoma cells are known to secrete CCL2 which is associated with increased tumor infiltration of macrophages [20-22]. However, there are mixed reports of good and bad prognosis due to increased infiltration of tumor associated macrophages in these studies [20-22]. In those studies, the level of tumor derived-CCL2 and its influence on $\mathrm{T}$ cell infiltration of tumor cells is unclear. In mouse tumor model system, there are indications that melanoma cells secreting high amounts of CCL2 attract macrophages resulting in tumor growth inhibition [23]. In another study, transfection of mouse CT-26 CRC cells with CCL2 gene resulted in decreased metastasis and increased susceptibility of tumor cells to macrophage lysis [24]. Thus, selective modulation of chemokine activity at the tumor site could attract immune cells resulting in tumor growth inhibition (reviewed in [25] and [1]). In mouse systems, ex vivo transduction of chemokines into tumor cells has provided potent tumor vaccines inducing tumor rejection, which was mediated by infiltrating $\mathrm{T}$ cells at the vaccine site. Infiltration of $\mathrm{T}$ cells into the tumor area was followed by rejection of both transduced and non-transduced tumor cells [11-13]. CD4 ${ }^{+} \mathrm{T}$-cell subsets have been implicated in tumor rejection induced by vaccination of mice with CCL19-transduced tumor cells [26], and CD8 ${ }^{+}$CTL were instrumental in tumor growth rejection in mice following intratumoral delivery of CCL20 or CXCL12 via adenovirus vectors [27] or injection of CCL16-expressing tumor cells. Both $\mathrm{CD}^{+}$and $\mathrm{CD}^{+} \mathrm{T}$ cells were required for tumor growth inhibition to occur in mice injected intratumorally with CCL21 [28].

It has been suggested that immunological intervention of cancer patients has been largely unsuccessful due to limited ability of $\mathrm{T}$ cells to infiltrate tumors in vivo $([29,30])$. Chemokines fused to anti-tumor Ab may be utilized to attract adoptively transferred tumor antigen (Ag) -specific $\mathrm{T}$ cells to the tumor site [31]. To develop immunotherapeutic strategies for cancer patients based on chemokines and their receptors, similar to the approaches already successfully used in mice, one must identify chemokines and their receptors involved in $\mathrm{T}$-cell migration toward tumor cells.

Recently, we have shown in an organotypic culture system (reconstruct) that migration of CTL derived from a CRC patient towards autologous tumor cells was mediated by chemokine receptor CXCR3 expressed by the $\mathrm{T}$ cells, and CXCL11 chemokine secreted by the autologous tumor cells [32]. In the present study, we show that migration of CTL derived from another CRC patient is dependent on CCL2 and CCR2.

\section{Materials and Methods \\ Cell lines}

CTL 007, CTL020, CRC cell line (WC007) and fetal colon fibroblast cell line (FCFB/1) were established and maintained in culture as previously described [32,33]. Ten additional primary tumor tissues were obtained from CRC patients of various disease stages whose $\mathrm{T}$ cells were analyzed for chemokine receptor expression (data from 4 patients whose $\mathrm{T}$ cells are positive for CCR2 are shown in Table 1). Blood and tissue specimens were obtained in compliance with Helsinki Declaration with informed consent approved by Institutional Review Board of Thomas Jefferson University Hospital, Fox Chase Cancer Center and The Wistar Institute (Approval number 2109169).

\section{Reagents}

The following monoclonal antibodies (mAb) were used: mAb Nok-1 to Fas ligand (BD-PharMingen, San Diego, $\mathrm{CA}$ ); mAb CH-11 to CD95 and anti-CD11a mAb (Immunotech, Westbrook, ME); fluoresceinated (FITC) or phycoerythrin (PE) -conjugated anti-CD:4, 8, 25, 29, 40, 40L, 44, 49a, 49b, 54 and 80; anti-CXCL-11 mAb; anti-human CCR:1, 2, 3, 5, 6, 7 and 9 mAb; anti- CXCR:1, 2, 3, 4, 5 and $6 \mathrm{mAb}$ (R\&D Systems, Minneapolis, MN); antihuman CCR:4, 8, and 10 mAb (Imgenex, San Diego, CA); anti-CCR11 and -CX3CR1 polyclonal Ab (Abcam, Cambridge, MA); FITC conjugated goat anti-mouse IgG (Invitrogen, Carlsbad, CA). Recombinant human CXCL11 was purchased from R\&D Systems.

\section{Chemokine determination by RT-PCR or ELISA}

mRNA was extracted from CRC cells $\left(5 \times 10^{6}\right)$ using Fast Track 2.0 mRNA isolation kit (Invitrogen). The primers used were 5'-GCC CGG TGT CAT CTT CCT AAC CAA GC-3' and 5'-AGG GGA CAG GGG AAC

Table 1 CCR2 expression by T-cell lines established from tumor infiltrating lymphocytes of CRC tissues

\begin{tabular}{llll}
\hline Patient $^{\text {a }}$ & \multicolumn{2}{c}{$\begin{array}{l}\text { T cell } \\
\text { phenotype }\end{array}$} & $\begin{array}{l}\text { Expression of CCR2 } \\
\text { (\% positive cells) }\end{array}$ \\
\cline { 1 - 2 }$\#$ & Dukes' Disease Stage & \\
\hline 296674 & A & CD4 & 58.8 \\
298884 & B & CD4/CD8 & 68 \\
1003485 & B & CD4/CD8 & 48.2 \\
05193 & B & CD4/CD8 & 27.4 \\
\hline
\end{tabular}

${ }^{\mathrm{a}}$ Representative data from 4 patients whose $\mathrm{T}$ cells were positive for CCR2 expression.

${ }^{b}$ CCR2 expression determined by FACS analysis. Data represented are from a single experiment and the Results were confirmed in at least two independent experiments. 
TCT CAG AGC AA-3' for CCL3; 5'-TGC TGC TTT TCT TAC ACC GCG AGG AA-3' and 5'-AGA AGG GAC AGG AAC TGC GGA GAG GA-3' for CCL4; 5'TCT GCA GCA CTT CTG TGT CTG-3' and 5'-GGA TCC TAG AAG GAG CTG GA-3' for CCL7; 5'-CAG TCC ATG AGA AGG AGT CCA-3' and 5'-AGA TCC TGC ACA GGA CTG TG-3' for CCL8; 5'-AGG GCA TGG GTT TTA TTA TAT ATA TAT-3' and 5'-TTT AAA AAT AAC TGA TAT TCA TGG-3' for CCL11; 5'-TCA TCT TTC CAC AAT AAC ATA TTT A-3' and 5'-GTT TAT TTG AGT ATT GCT GAT CTT T-3' for CCL13; 5'-GGA CTT CCT GGA TCC TCC TC-3' and 5'-AGC AGT CAG CAG CAA AGT GA-3' for CCL15; 5'ATG GCC CTG CTA CTG GCC CTC AGC CTG-3' and 5' - TTA ACT GCT GCG GCG CTT CAT CTT GGC-3' for CCL19; 5'-TGT AGG GCG ACG GTT TTA-3' and 5'-TCC ACC ACA ACA TGC AG-3' for CCL25; 5'-GGC CCT GCC CTT ATA GC-3' and 5'CTA ACT TGG GGT TGA CAT T-3' for CXCL1-3; 5'TGT TGA GAG AGC TGC G-3' and GGG TTC AGA GAC CTC CA-3' for CXCL5; 5'-GAA GTG GTA GCC TCC C-3' and 5'-GCT TTC CCC CAC ACT C-3' for CXCL6; 5'-TCC GCT GCA TGT GTA TAA AG-3' and 5'-ATA GGT ATC CTG AAT AAA TGA GAA C-3' for CXCL7; 5'-CAT GCT GGT GAG CCA AGC AGT TTG AA-3' and 5'-CAC TTC TGT GGG GTG TTG GGG ACA AG-3' for CXCL9; 5'- CGA TGC CTA AAT CCC AAA TCG AAG CA-3' and 5'-AAT TGC TGG ACT CCT TTG GGC AGT GG-3' for CXCL11; 5'-ATG AAC GCC AAG GTC GTG GTC-3' and 5'-TGG CTG TTG TGC TTA CTT GTT T-3' for CXCL12; 5'-TCT CTC CAG GCC ACG GTA TTC-3' and 5'-ACC ATT TGG CAC GAG GAT TCA C-3' for CXCL13. CCL21 primer was purchased from Biosource (Camarillo, CA) and CCL2, CCL5, CXCL8 and CXCL10 primers were purchased from R\&D Systems. PCR reactions were performed for 35 cycles $\left(94^{\circ} \mathrm{C}, 45 \mathrm{sec} ; 60^{\circ} \mathrm{C}\right.$ for CCL4, CCL19, CCL21, CXCL1, CXCL5, CXCL6, CXCL7, CXCL9, and CXCL11; $56^{\circ} \mathrm{C}$ for CXCL12, $55^{\circ} \mathrm{C}$ for CCL2, CCL3, CCL5, CCL25, CXCL8 and CXCL10; $52^{\circ} \mathrm{C}$ FOR CCL7 and CCL15; $48^{\circ} \mathrm{C}$ for CCL8, CCL11 and $\left.\mathrm{CCL} 13,45 \mathrm{sec} ; 72^{\circ} \mathrm{C}, 45 \mathrm{sec}\right)$ using the SuperScript OneStep RT-PCR kit (Invitrogen). All PCR involved an initial denaturation step at $94^{\circ} \mathrm{C}$ for $45 \mathrm{sec}$ to $1.5 \mathrm{~min}$ and a final extension step for $7 \mathrm{~min}$ at $72^{\circ} \mathrm{C}$. All PCR products were analyzed using $10 \%$ novex-TBE gel (Invitrogen). Supernatants obtained from CRC cells on day 6 of culture were tested for the presence of CCL2, CCL3, CCL15, CCL19, CCL21 and CXCL11 using ELISA kits (R\&D Systems).

\section{Phenotyping}

Phenotyping of tumor cells and T cells was performed as described [32]. In brief, cultured cells were incubated with saturating concentrations of FITC or PE-conjugated $\mathrm{mAb}(5 \mu \mathrm{g} / \mathrm{ml})$ detecting human lymphocyte and tumor markers in FACS buffer for $1 \mathrm{~h}$ at $4^{\circ} \mathrm{C}$, followed by excess $\mathrm{mAb}$ removal by washing in FACS buffer. Binding of the mAb was analyzed as described [32].

\section{T-cell migration in organotypic CRC culture (reconstruct)}

Organotypic CRC cultures were initiated as described [32]. In brief, $1.8 \times 10^{5}$ fetal fibroblast cells were mixed with collagen matrix $(450 \mu \mathrm{l})$ and plated in a 24 -well tissue culture treated plate (Corning, Corning, NY). After $24 \mathrm{~h}$, WC007 CRC cells $\left(1 \times 10^{5}\right)$ were seeded on top of the collagen layer and after $24 \mathrm{~h}$, a separating layer of fibroblasts in collagen matrix $(100 \mu \mathrm{l}, 500 \mu \mathrm{m})$ was added on top of the CRC cells. CTLs $\left(1-10 \times 10^{5}\right)$ were mixed with fibroblasts $\left(1 \times 10^{5}\right)$ in $250 \mu \mathrm{l}$ collagen matrix and plated on top of the separating layer. In some cultures, CRC cells were stained with CellTracker Blue CMAC $\left(15 \mu \mathrm{M}\right.$, for $40 \mathrm{~min}$ at $37^{\circ} \mathrm{C}$; Invitrogen) and CTL were pre-stained with CFDA-Green (5 $\mu \mathrm{M}$, Invitrogen). For control reconstruct, autologous PHA blasts (PBMC stimulated with PHA [1\% v/v, Invitrogen] and propagated in recombinant interleukin (IL)-2 $[20 \mathrm{U} / \mathrm{ml}$; a gift from the Biological Resources Branch, National Cancer Institute-Frederick Cancer Research and Development Center, Frederick, MD] for 3-4 weeks) were used. Reconstructs were incubated in medium (50\% DMEM, 50\% CRC medium supplemented with $2 \%$ human $A B$ serum). On various days after addition of $\mathrm{T}$ cells reconstructs were fixed and processed for histological evaluation as described earlier [32]. The percentage of apoptotic tumor cells was determined by counting apoptotic nuclei and intact tumor cells in sections stained with H\&E.

\section{Blocking of T-cell migration in reconstruct}

T-cell migration in the reconstruct was performed in the presence of anti-chemokine or chemokine receptor Abs $(10 \mu \mathrm{g} / \mathrm{ml})$ or isotype-matched control $\mathrm{Ab}$ added above the separating layer, followed by addition of CTLfibroblast collagen layer [32]. To evaluate whether excess chemokine can block migration of $\mathrm{T}$ cells, the chemokine $(50 \mathrm{ng} / \mathrm{ml})$ was added into the medium on top of the T-cell layer. The percentage of apoptotic tumor cells in the presence and absence of inhibitor was determined and the percentage of inhibition of apoptosis by Abs or chemokines was calculated [32].

\section{Chemotaxis assay}

CTL migration was evaluated using a 24-well, Transwell plate $(8.0-\mu \mathrm{m}$ pore size; Corning, Corning, NY) as described earlier [34]. In brief, $\mathrm{T}$ cells were washed once with RPMI1640 medium, cell count re-adjusted $\left(5 \times 10^{5}\right.$ cells $/ \mathrm{mL})$ in T cell medium [33] and an aliquot $(100 \mu \mathrm{L})$ of $\mathrm{T}$-cell suspension was placed in the top chamber of 
the Transwell. Bottom chamber of Transwell plate received chemokine $(500 \mu \mathrm{L}$ in $\mathrm{T}$ cell medium $)$ at the indicated concentration prior to the addition of $\mathrm{T}$ cells in the top chamber. After $90 \mathrm{~min}$ incubation at $37^{\circ} \mathrm{C}$ in a $5 \% \mathrm{CO} 2$ atmosphere, the top chamber was removed, and the number of $\mathrm{T}$ cells that had migrated into the bottom chamber was counted under the microscope.

\section{Immunohistochemistry}

Formalin-fixed paraffin-embedded sections $(5 \mu \mathrm{m})$ were deparaffinized by sequential application of Sub-xylene substitute $(3 \times 10 \mathrm{~min}$, Surgipath Medical Industries, Richmond, IL) and re-hydrated through a graded series of ethanol after which they were rinsed shortly in phosphate buffered saline (PBS). In situ end labeling (ISEL) was performed as described earlier [35]. Briefly: sections were air-dried and digested with proteinase $\mathrm{K}(1.25 \mu \mathrm{g} /$ $\mathrm{ml}$ in $50 \mathrm{mM}$ Tris- $\mathrm{HCl}, 1 \mathrm{mM}$ EDTA, $\mathrm{pH}$ 8.0) for $30 \mathrm{~min}$ at $40^{\circ} \mathrm{C}$ in a humidified chamber. After incubation, sections were rinsed in distilled water followed by sequential changes of ethanol (70-95\%), and air dried. Sections were end-labeled by incubating with biotinylated dCTP, dATP, and non biotinylated dTTP, dGTP (0.01 mM each, Invitrogen) in the presence of DNA polymerase Klenow I fragment (Promega Corporation, Madison, WI) for $60 \mathrm{~min}$ at $40^{\circ} \mathrm{C}$. Sections were blocked later for endogenous peroxidase activity with $\mathrm{H}_{2} \mathrm{O}_{2}(0.3 \%$ in methanol, for $20 \mathrm{~min}$ at $\mathrm{RT}$, serially rinsed with distilled water and PBS) and the biotinlabeled DNA sequences were detected by horseradish peroxidase (HRP)-conjugated streptavidin for $40 \mathrm{~min}$ at $37^{\circ} \mathrm{C}$. Slides were washed and incubated with 2', 5'diaminobenzidine (DAB, Vector Laboratories, Burlingame, CA) followed by counterstaining with hematoxylin. Caspase staining was performed using an Ab specific for the active form of caspase 3 (present only in cells undergoing apoptosis). In brief, sections were blocked for endogeneous peroxidase as above, followed by addition of avidin/biotin and protein blocking using respective blocking kits (Vector Laboratories and Immunotech). After blocking, slides were incubated with rabbit antihuman active caspase 3 polyclonal Ab (1:1500 dilution, $\mathrm{R}$ \& D Systems), at $4^{\circ} \mathrm{C}$ overnight, followed by incubation with biotinylated anti-rabbit Ab and HRP-conjugated streptavidin (both from Vector Laboratories). Signals were visualized with 2', 5' DAB as the substrate. The slides were counterstained with hematoxylin. Normal rabbit gamma globulin was used as a negative control (MP Biomedical Services, Santa Ana, CA).

\section{Statistical analyses}

Differences between experimental and control values were analyzed for significance by 2 -sample Student's $t$-test.

\section{Results}

Functional characteristics of CTL007 in reconstruct

We have shown that CTL007 specifically lyses autologous WC007 colon carcinoma target cells in an HLAclass I (A1) restricted manner and does not have any inhibitory T cell function [33]. Studies of CTL007 in the reconstruct showed that these CTL induce tumor cell apoptosis. Apoptosis of WC007 cells was determined microscopically in H\&E-stained cultures, and by histochemistry (Figure 1B [a-f]). Reconstruct containing autologous PHA blasts has large numbers of healthy WC007 tumor cells (Figure 1B [a]). In contrast, culture established with CTL007 shows greater proportion of dead tumor cells (Figure 1B [b]) which was further confirmed by apoptosis assays [caspase staining] (Figure 1B [c and d]) and in situ end labeling (ISEL; Figure 1B [e and f]). Tumor cell apoptosis was quantified microscopically by enumerating apoptotic tumor cells in H\&E-stained cultures (Table 2). The CTL induced significant apoptosis in the autologous CRC cells, as compared to reconstructs with tumor cells alone or tumor cells plus PHA blasts. The percentage of apoptotic WC007 cells depended on $\mathrm{E}$ : $\mathrm{T}$ ratios in the reconstruct (Table 2). CTL007 showed significantly $(\mathrm{p}=0.005)$ higher lytic capacity on day 5 of lymphocyte culture compared to day 3 , irrespective of the presence or absence of a separating collagen/fibroblast layer (Figure 2). Thus, longer exposure of tumor cells to CTL007 results in increased apoptosis of tumor cells.

Migration of CTL was visualized in reconstructs using T cells labeled with CFDA-Green and tumor cells labeled with CMAC-Blue. Lymphocytes migrated from the top layer of collagen and fibroblasts through a separating layer of collagen and fibroblasts toward WC007 tumor cells (Figure 1B [h]). Although a small proportion of PHA blasts also migrated to the tumor cell layer, the PHA blasts did not induce significant apoptosis in the tumor cells (Figure 1B [a, c, e, g; Table 2).

\section{Phenotypic characteristics of CTL007 and WC007 CRC cells}

CTL007 and WC007 CRC cells were phenotyped with special emphasis on molecules that might be involved in the interactions of these cells with each other and components of the reconstruct (Table 3). CTL007 is a CD4+ (>96\%) $\mathrm{T}$ cell line that expresses several adhesion and co-stimulatory molecules as described in Table 3. It also expresses $\alpha 2$ (CD49b) and $\beta 1(C D 29)$ integrins (Table 3) that are important for $\mathrm{T}$-cell interaction with collagen in the reconstruct, which might result in $\mathrm{T}$-cell activation $[36,37]$. In addition, $T$ cells also express LFA-1a (CD11a), ICAM-1 (CD54), and CD44 (Table 3) and these molecules facilitate interaction of the lymphocytes 


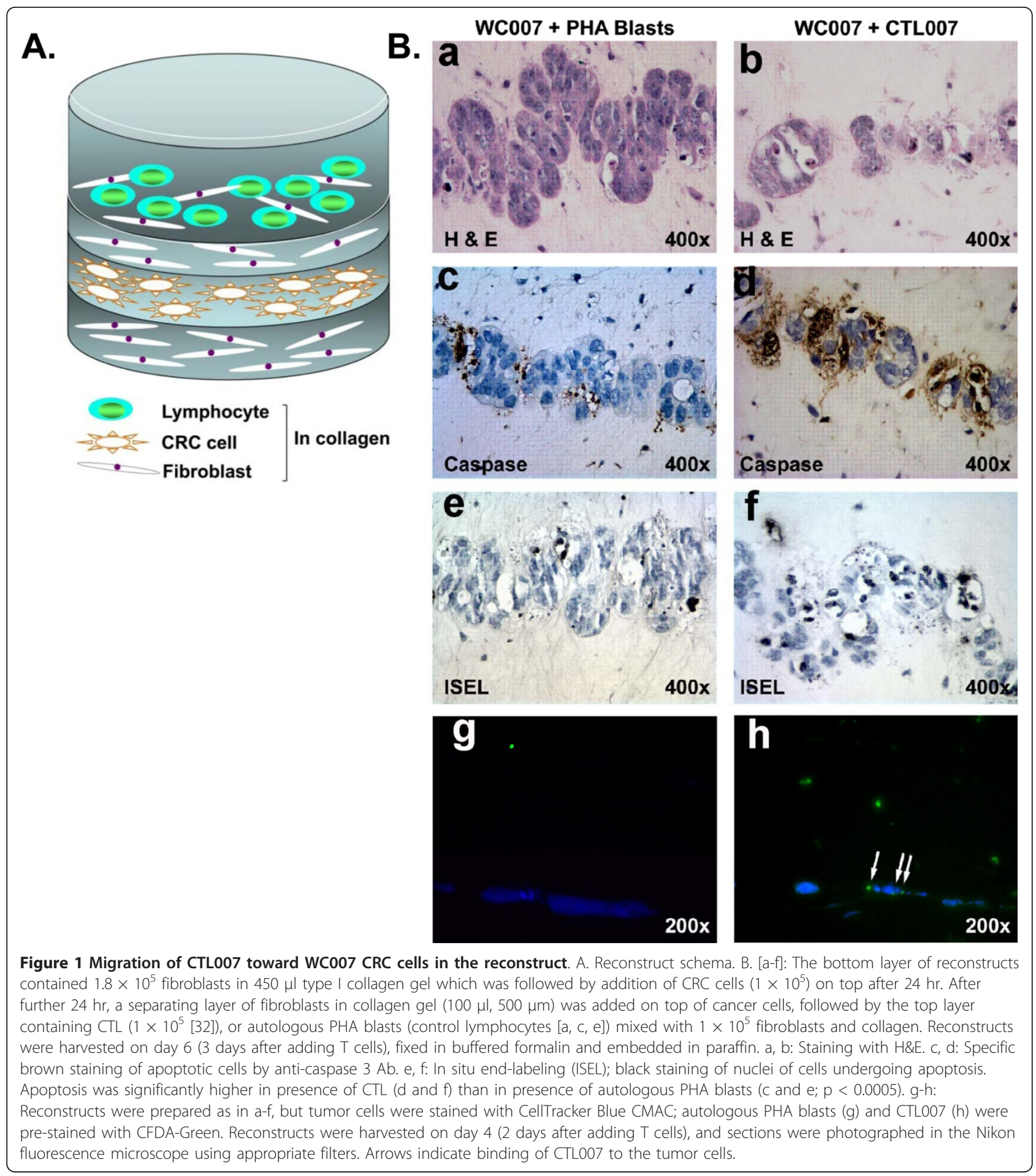

with fibroblasts in the reconstruct $[38,39]$. This interaction results in the activation of both lymphocytes and fibroblasts through secretion of growth and survival factors, cytokines, and fibronectin [38-41].

WC007 CRC cells express both HLA class I and II molecules, FAS, ICAM-1, and various integrins.
Expression of $\alpha 2$ and $\beta 1$ integrins by the CRC cells may facilitate their binding to collagen [42]. CRC cells also express FAS ligand $(<19 \%)$ and are positive for B7-1 and ICAM-1. B7-1 and ICAM-1 on the CRC cells potentially interact with CD28 and LFA-1a on the CTL, respectively, which may result in T-cell stimulation [43]. 
Table 2 Apoptosis induction by CTL007 in reconstruct with autologous WC007 CRC cells*

\begin{tabular}{|c|c|c|c|c|}
\hline Lymphocytes & $\mathrm{E}: \mathrm{T}$ & $\begin{array}{l}\text { Total number of tumor cells mean } \\
\pm \text { SD/field (10 fields) }\end{array}$ & $\begin{array}{l}\text { Number of apoptotic tumor cells mean } \\
\pm \text { SD/field (10 fields) }\end{array}$ & $\begin{array}{l}\text { Percentage of apoptotic cells, mean } \\
\pm \text { SD/field (10 fields) }\end{array}$ \\
\hline \multicolumn{5}{|l|}{ Experiment I } \\
\hline CTL007 & $1: 1$ & $80.5 \pm 38.8$ & $23.5 \pm 8.7$ & $31.7 \pm 11^{c, d}$ \\
\hline PHA blast & $1: 1$ & $136.2 \pm 54.8$ & $15.9 \pm 6.8$ & $12.1 \pm 3.9^{c}$ \\
\hline $\begin{array}{l}\text { No } \\
\text { lymphocytes }\end{array}$ & NA & $90.1 \pm 3.5$ & $7.1 \pm 2.8$ & $8.1 \pm 3.5^{d}$ \\
\hline \multicolumn{5}{|l|}{ Experiment II } \\
\hline CTL007 & $10: 1$ & $116.7 \pm 19.4$ & $94.8 \pm 19$ & $79.5 \pm 6.7^{\mathrm{a}, \mathrm{b}}$ \\
\hline PHA blast & $10: 1$ & $118.3 \pm 23.6$ & $34.7 \pm 11.8$ & $27.5 \pm 4.7^{\mathrm{a}}$ \\
\hline $\begin{array}{l}\text { No } \\
\text { lymphocytes }\end{array}$ & NA & $121.1 \pm 22.3$ & $25.8 \pm 10.7$ & $21.3 \pm 10.1^{b}$ \\
\hline
\end{tabular}

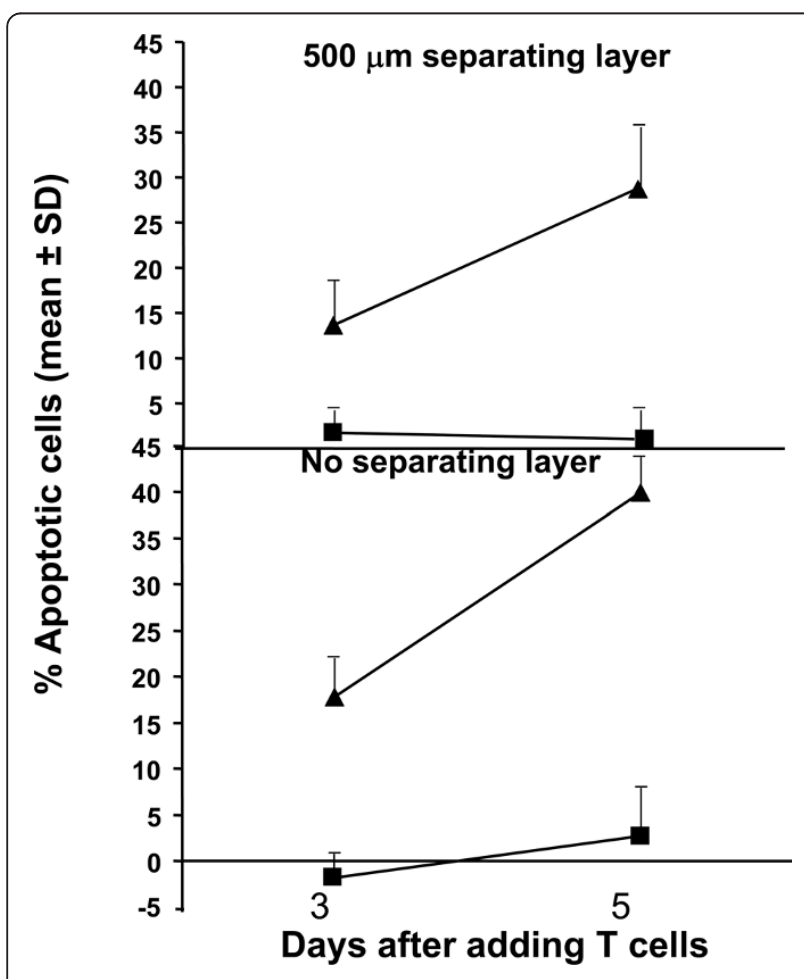

Figure 2 Time course of WC007 CRC apoptosis induction by CTL007 in reconstruct. Reconstructs were prepared as in Fig.1. An E: T ratio of 2:1 was used in this assay, reconstructs harvested on day 6 or 8 ( 3 or 5 days after adding T cells), fixed, processed and enumerated as described in Fig.1. Values represent mean percentage of apoptosis/field (total of 10 fields), of cultures with lymphocytes corrected by the value obtained without lymphocytes, \pm SD (bars). Percent apoptotic tumor cells of reconstruct cultures with CTL $(\mathbf{\Delta})$ were significantly higher than cultures with PHA blast (-) on both days, for cultures with and without separating layer (at $p<0.05$ level). Percent apoptotic tumor cells of reconstruct cultures was significantly $(p=0.005)$ higher on day 5 than on day 3 for cultures with and without separating layer. The separating layer had no significant effect on percent apoptotic cells.
Thus, several phenotypic markers are expressed by CTL007 and WC007, which are known to facilitate interactions between these cells and between the lymphocytes or tumor cells and collagen or fibroblasts in the reconstruct, leading to activation of $\mathrm{T}$ cells as well as $\mathrm{T}$-cell migration toward tumor cells.

Chemokine and chemokine receptor involved in CTL007 migration toward WC007 cells

CTL007 express the chemokine receptors CCR1, CCR2, CCR3, CCR5, CCR7, CCR9, CXCR1, CXCR2, CXCR3, CXCR4, and CXCR5 (Table 4). For each chemokine

\section{Table 3 Phenotypic and functional markers of anti-CRC} CTL007 and autologous WC007 tumor cell line

\begin{tabular}{lll}
\hline Parameter investigated $^{\mathbf{a}}$ & \multicolumn{2}{c}{ Cell lines (\% cells positive) } \\
\cline { 2 - 3 } & CRC WC007 & CTL007 \\
\hline HLA Class I & 99.8 & 95.6 \\
HLA Class II & $<1$ & 60 \\
CD4 & NA & 96 \\
CD8 & NA & $<1$ \\
CD25 & $<1$ & 30 \\
CD40L & 2.1 & 13 \\
CD44 & 48 & 79.7 \\
CD80 (B7-1) & 85 & $<1$ \\
CD49a ( $\alpha 1$ integrin) & 48.2 & 26.1 \\
CD49b ( $\alpha 2$ integrin) & 63.2 & 32.5 \\
CD29 ( $\beta$ 1 integrin) & 56.9 & 79.8 \\
CD95 (FAS) & 65.1 & 95.1 \\
CD95L (FASL) & 19 & $<1$ \\
CD54 (ICAM-1) & 84.5 & 89.3 \\
CD11a (LFA-1a) & $<1$ & 84.2 \\
\hline
\end{tabular}

$\mathrm{NA}=$ not applicable.

${ }^{a}$ All markers were determined by flow cytometry and data represented are from a single experiment and the Results were confirmed in at least two independent experiments. 
Table 4 Chemokine receptors expressed by CTL007, and chemokines produced by WC007 CRC cells

\begin{tabular}{|c|c|c|c|c|}
\hline \multicolumn{2}{|c|}{ Chemokine receptors expressed by CTL007 ${ }^{\mathrm{a}}$} & \multicolumn{3}{|l|}{ Chemokines } \\
\hline \multirow[t]{2}{*}{ Chemokine receptors } & \multirow{2}{*}{$\begin{array}{l}\% \text { positive } \\
\text { cells }\end{array}$} & \multirow{2}{*}{$\begin{array}{l}\text { Known to bind } \\
\text { to receptor }\end{array}$} & \multicolumn{2}{|c|}{ Expressed by WC007 } \\
\hline & & & RT-PCR & ELISA (pg/ml) \\
\hline \multirow[t]{5}{*}{$\overline{\text { CCR1 }}$} & 5.7 & CCL3 & + & $<30^{c}$ \\
\hline & & CCL5 & - & $N D^{d}$ \\
\hline & & CCL7 & - & ND \\
\hline & & CCL13 & - & ND \\
\hline & & CCL15 & + & 35 \\
\hline \multirow[t]{4}{*}{ CCR2 } & 65 & CCL2 & + & 51.6 \\
\hline & & CCL7 & - & ND \\
\hline & & CCL8 & - & ND \\
\hline & & CCL13 & - & ND \\
\hline \multirow[t]{5}{*}{ CCR3 } & 19.4 & CCL7 & - & ND \\
\hline & & CCL8 & - & ND \\
\hline & & CCL11 & - & ND \\
\hline & & CCL13 & - & ND \\
\hline & & CCL24 & - & ND \\
\hline \multirow[t]{3}{*}{ CCR5 } & 10.1 & CCL3 & + & $<30^{c}$ \\
\hline & & CCL4 & + & 16 \\
\hline & & CCL5 & - & ND \\
\hline \multirow[t]{2}{*}{ CCR7 } & 9.5 & CCL19 & + & $<20^{c}$ \\
\hline & & CCL21 & + & $<30^{c}$ \\
\hline CCR9 & 16.4 & CCL25 & - & ND \\
\hline \multirow[t]{2}{*}{ CXCR1 } & 16.7 & CXCL6 & - & ND \\
\hline & & CXCL8 & - & ND \\
\hline \multirow[t]{5}{*}{ CXCR2 } & 15.4 & CXCL1 & - & ND \\
\hline & & CXCL5 & - & ND \\
\hline & & CXCL6 & - & ND \\
\hline & & CXCL7 & - & ND \\
\hline & & CXCL8 & - & ND \\
\hline \multirow[t]{4}{*}{ CXCR3 } & 16.9 & CXCL9 & - & ND \\
\hline & & CXCL10 & - & ND \\
\hline & & CXCL11 & + & 35.6 \\
\hline & & CXCL13 & - & ND \\
\hline CXCR4 & 17.6 & CXCL12 & - & ND \\
\hline CXCR5 & 32.4 & CXCL13 & - & ND \\
\hline
\end{tabular}

${ }^{a}$ Chemokine receptor expression as determined by FACS and the following chemokine receptors were not expressed by CTL007:CCR4, CCR6, CCR8, CCR10, CX3CR1.

${ }^{b}$ Chemokine expression was detected by RT-PCR and if they were positive in RT-PCR, then protein expression was confirmed by ELISA. CCL3, CCL19 and CCL21 mRNA were detected in WC007 cells by RT-PCR, but the protein expression was below detection limit of.

ELISA. Data represented are from a single experiment and the Results were confirmed in at least two independent experiments.

'below detection limit.

${ }^{\mathrm{d} N D-N o t}$ determined.

receptor, with the exception of CCR3, CXCR1, CXCR2, CXCR4, and CXCR5 the corresponding chemokine(s) was expressed by WC007 CRC cells, as determined by RT-PCR and protein expression confirmed by ELISA (Table 4).

We evaluated possible roles of chemokine receptors CCR1, CCR2, CCR3, CCR5, CCR7 and CXCR3 expressed by the $\mathrm{T}$ cells in the migration of the CTL cells toward
CRC cells in the reconstruct. T-cell migration was measured as a function of tumor cell apoptosis and not absolute number of $\mathrm{T}$ cells at the tumor cell layer, since $\mathrm{T}$ cells may themselves undergo apoptosis after inducing tumor cell apoptosis and one T cell may induce apoptosis in more than one tumor cell. Only apoptotic tumor cells, and not $\mathrm{T}$ cells, were counted. Apoptotic tumor cells could be distinguished from apoptotic $\mathrm{T}$ cells based on 
size difference. However, evaluation of apoptotic tumor cells does not allow us to distinguish between $\mathrm{T}$ cells with high migratory and low lytic activity and $\mathrm{T}$ cells with low migratory and high lytic activity. Nevertheless the ratio of apoptotic tumor cells correlates with CTL migration. Blocking of chemokine receptor CCR2 but not CCR1, CCR3, CCR5, CCR7 or CXCR3 on CTL007 with Abs significantly inhibited tumor cell apoptosis (Table 5). To determine the involvement of CCR2 ligand (CCL2) in $\mathrm{T}$ cell migration and apoptosis, excess recombinant CCL2 or anti-CCL2 Ab was added to the top of the T-cell layer or to the separating layer. Both excess CCL2 and anti-CCL2 Ab were able to inhibit $\mathrm{T}$ cell migration and tumor cell apoptosis significantly ( $<<0.05$, Table 5$)$. Involvement of CCR2 and CCL2 in induction of migration of CTL007 was further confirmed in chemotaxis assay using Transwell plates (Figure 3). Treatment of $\mathrm{T}$ cells with anti-CCR2 Ab significantly inhibited ( $\mathrm{p}<$ 0.001) the migration of CTL007 toward recombinant CCL2, whereas control IgG treatment of $\mathrm{T}$ cells had no effect (Figure 3). These data further confirm of our finding that CCR2 receptor on T cells and CCL2 secreted by tumor cells are involved in migration of $\mathrm{T}$ cells towards tumor cells. Predominant expression of CCR2 (65\%) when compared to other chemokine receptors (most $<20 \%$ except CXC5; Table 4 Figure 3B) further supports the role of CCR2 in $\mathrm{T}$ cell migration. Relative high expressions of CCR2 (65\%) on CTL007 and CXCR3 (48.3\%) on CT020 (Figure 3B) respectively suggests dominant expression of certain chemokine receptors (CCR2 for CTL007 and CXCR3 for CTL020) may be a decisive factor in migration of lymphocytes.

CCR2 and CCL2 expression by T cells and tumor cell lines, respectively, derived from additional CRC patients

We investigated the distribution of CCR2 and CCL2 in $\mathrm{T}$ cells and tumor cell lines, respectively, established from specimens of additional CRC patients. Expression of CCR2 receptor and its ligand by the cells of additional CRC patients would suggest that involvement of the receptor/ligand in $\mathrm{T}$-cell migration toward tumor cells may not be a unique observation made in a single CRC patient, but may be found in other patients. Ten tumor reactive T-cell lines derived from TIL of additional CRC patients were analyzed for CCR2 expression and four of these showed CCR2 expression (Table 1). Furthermore, two of the established CRC cell lines produced CCL2 (data not shown).

\section{Discussion}

We have demonstrated here that CTL007 migrate through a $500 \mu \mathrm{m}$ collagen/fibroblast separating layer toward tumor cells, resulting in tumor cell apoptosis. We have also shown that migration is dependent on
CCR2 expressed by $\mathrm{T}$ cells and CCL2 secreted by tumor cells.

Our recently developed novel three-dimensional culture system offers a unique way of studying migration of leukocytes toward tumor cells and the factors that influence leukocyte migration under physiological conditions $[32,34]$. As described in our previous studies, human CRC is grown in vitro under three-dimensional conditions using a mixture of collagen and fibroblasts [32,44]. Interaction of $\alpha 2$ and $\beta 1$ integrins on CRC-specific $\mathrm{T}$ cells with collagen and the presence of activated fibroblasts help to maintain Ag-specific T cells in a state of activation in absence of exogenous addition of IL-2 $[36,37]$. In addition, $T$ cells could interact with fibroblasts via adhesion molecules like LFA-1a, ICAM-1 and CD44 which could in turn stimulate fibroblasts to secrete inflammatory cytokines such as IL-1, IL-6, IL-7 $[38,39]$, and fibronectin [41]. IL-1 could stimulate $\mathrm{T}$ cells to express IL-2 receptor and induce secretion of IL-2 [45]. IL-6 and IL-7 are T-cell survival factors [46], and fibronectin stimulates predominantly resting lymphocytes [41]. Other investigators have used collagen matrices to study interaction of leukocytes with tumor cells, but they have not demonstrated CTL migration resulting in tumor cell apoptosis in a culture system similar to the reconstruct cultures shown here [47-49].

In the present study, CCL2 produced by CRC cells attracts CTL through binding of CCL2 to its corresponding chemokine receptor CCR2 on the T cells. This was demonstrated by blocking of $\mathrm{T}$-cell migration in presence of addition of excess chemokine CCL2 in the $\mathrm{T}$-cell layer of the reconstruct or the addition of Abs to CCL2 or CCR2, each applied on top of the separating collagen/fibroblast layer. Involvement of CCR2 in T-cell migration was further confirmed in chemotaxis assay in Transwell plate experiment by treating $\mathrm{T}$ cells with antiCCR2 Ab. Although CTL007 has several chemokine receptors matching chemokine produced by CRC cells, predominant expression of CCR2 (65\%) by the T cells and the relatively higher amount of CCL2 secretion by tumor cells may have been a decisive factor in T-cell migration.

Many carcinomas, including breast, colorectal, pancreatic and renal carcinomas, and neuro-ectodermal tumors such as melanomas, medulloblastomas, neuroblastomas and glioblastomas are known to produce CCL2 (reviewed in [1]; [20-22,50]. CCL2 secretion by tumor cells can aid in tumor progression, angiogenesis and metastasis $[1,5,10]$. Also, the secretion of CCL2 by tumor cells results in infiltration of tumor cells by leukocytes including $\mathrm{T}$ cells, NKT cells and macrophages (reviewed in [1]; [20-22]). To our knowledge, the role of CCL2-dependent T-cell migration in CRC is largely unknown. In mouse tumor model systems, melanoma cells secreting high amounts of CCL2 
Table 5 Induction of tumor apoptosis by CTL007 is inhibited by anti-CCR2 and CCL2 Abs and excess CCL2a

\begin{tabular}{|c|c|c|c|c|}
\hline $\begin{array}{l}\text { Blocking } \\
\text { agent }\end{array}$ & $\begin{array}{l}\text { Number } \\
\text { of } \\
\text { tumor } \\
\text { cells/ } \\
\text { field } \\
\text { (10 } \\
\text { fields) }\end{array}$ & $\begin{array}{l}\text { Number of } \\
\text { apoptotic cells/ } \\
\text { field ( } 10 \text { fields) }\end{array}$ & $\begin{array}{l}\% \text { of } \\
\text { apoptotic } \\
\text { cells }\end{array}$ & $\begin{array}{l}\% \text { of tumor } \\
\text { cell apoptosis } \\
\text { inhibition }\end{array}$ \\
\hline None & $21.8 \pm 9.7$ & $8.2 \pm 9$ & $40.5 \pm 9.7^{b}$ & - \\
\hline $\begin{array}{l}\text { Control } \\
\lg G\end{array}$ & $21 \pm 2.2$ & $8.4 \pm 1.1$ & $40.1 \pm 4.9^{c}$ & - \\
\hline $\begin{array}{l}\text { Anti-CCR1 } \\
\text { Ab }\end{array}$ & $22 \pm 3.4$ & $10.0 \pm 1.6$ & $45.6 \pm 5.0$ & -13.7 \\
\hline $\begin{array}{l}\text { Anti-CCR2 } \\
\mathrm{Ab}\end{array}$ & $19.6 \pm 1.1$ & $2.6 \pm 0.5$ & $13.2 \pm 2.3^{c}$ & 67.1 \\
\hline $\begin{array}{l}\text { Anti-CCR3 } \\
A b\end{array}$ & $22.4 \pm 2.8$ & $9.2 \pm 1.9$ & $40.7 \pm 4.2$ & 1.5 \\
\hline $\begin{array}{l}\text { Anti-CCR5 } \\
\text { Ab }\end{array}$ & $21 \pm 2.6$ & $9.6 \pm 1.8$ & $45.5 \pm 3.8$ & -13.4 \\
\hline $\begin{array}{l}\text { Anti-CCR7 } \\
\mathrm{Ab}\end{array}$ & $18.8 \pm 2.4$ & $7.2 \pm 1.6$ & $38.0 \pm 4.1$ & 5.2 \\
\hline $\begin{array}{l}\text { Anti- } \\
\text { CXCR3 } \\
\text { Ab }\end{array}$ & $21.4 \pm 1.5$ & $9.2 \pm 0.8$ & $43.1 \pm 1.8$ & -7.5 \\
\hline CCL2 & $21.4 \pm 4.4$ & $3.6 \pm 1.1$ & $17.2 \pm 6.1^{b}$ & 57.5 \\
\hline $\begin{array}{l}\text { Anti-CCL2 } \\
\mathrm{Ab}\end{array}$ & $17.8 \pm 2.6$ & $2.2 \pm 0.4$ & $12.7 \pm 3.8^{c}$ & 68.6 \\
\hline
\end{tabular}

Reconstructs consisted of a bottom layer of collagen and fibroblasts, followed by a tumor cell layer and a separating layer of collagen and fibroblasts. Antichemokine receptor or control Abs were added, followed by a top layer containing CTL mixed with fibroblasts and collagen (E: $T=3: 1$ ). Excess $C C L 2$ $(50 \mathrm{ng} / \mathrm{ml})$ was added to the T-cell layer. Percentage of apoptotic tumor cells in 6 day cultures was determined. ${ }^{(b, c)}$ Values with same letter differ significantly from each other $(p<0.05)$. Data represented are from a single experiment and the Results were confirmed in at least two independent experiments.

attract macrophages resulting in inhibition of tumor growth. However, tumor cells secreting low amounts of CCL2 promote tumor growth by stimulating angiogenesis [23]. In another study, tumor cells transfected with CCL2 showed decreased metastasis due to increased infiltration of macrophages and susceptibility of tumor cells to lysis by infiltrating macrophages [24]. Thus, patients may be vaccinated with chemokinetransduced tumor cells [51] or tumor-associated Ags fused to chemokines [52]; alternatively, patients may be treated with anti-tumor Ab/chemokine fusion protein, which may attract adoptively transferred lymphocytes to the tumor area $[12,52,53]$. In light of the mouse study by Nesbit et.al., [23], one needs to carefully modulate the expression of CCL2 to attract immune cells toward tumor cells. Thus, chemokines may be useful for immunotherapy of cancer patients.

In addition to therapeutic implications, the results of our study have prognostic potential. Infiltration of CRC with $\mathrm{T}$ lymphocytes is correlated with a favorable prognosis [54], and chemokine receptor expression by $\mathrm{T}$ lymphocytes as well as chemokine production by tumor cells should be explored for their possible association with prognosis. Identification of tumor cells secreting CCL2 or T-cells expressing CCR2 in the tumor microenvironment could be a useful prognostic marker in CRC patients $[17,18,22,55-58]$. In our earlier study, we have shown that migration of CTL derived from a CRC patient towards autologous tumor cells was mediated by CXCR3 expressed by the T cells, and CXCL11 chemokine secreted by the autologous tumor cells [32]. In the present study, we show that migration of CTL is dependent on CCL2 and CCR2. Presence of CCR2 in $\mathrm{T}$ cells obtained from four of the ten additional patients suggests that CCR2 expression may not be that uncommon. It is likely that in each individual CRC patient a unique chemokine/chemokine receptor pair might be involved in attraction of $\mathrm{T}$ cells towards tumor cells. Hence, it is essential to identify the chemokine/chemokine receptor pair responsible for

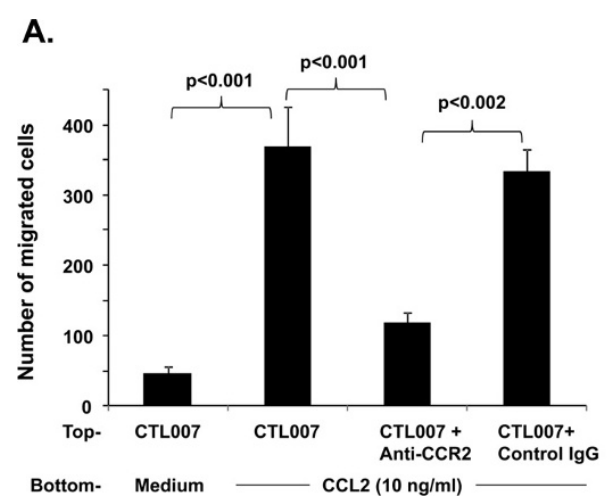

B.

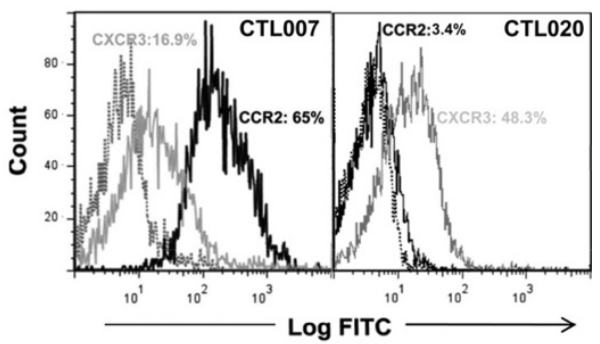

Figure 3 A. CTL007 migrates toward CCL2 in Transwell. T cells were placed in the top chamber of the Transwell. CCL2 (10 ng/ml) in T cell medium, or T cell medium alone were added to the bottom of the Transwell (duplicate wells). After 90 min of culture, the number of migrated cells in the bottom chamber was counted under the microscope. Some T cell cultures were pre-incubated and treated with saturating concentration $(10 \mathrm{\mu g} / \mathrm{ml})$ of mouse anti-CCR2 Ab or mouse lgG as control. B. Expression of CCR2. T cells grown in log phase were incubated with either anti-CCR2 or anti-CXCR3 Ab (black or grey solid line) or mouse IgG control (dotted line) in RPMI 1640 with 5\% human AB serum for $1 \mathrm{~h}$ at $4^{\circ} \mathrm{C}$. After washing, FITC-labeled anti-mouse lgG was added. Expression of chemokine receptors was detected by flow cytometry. 
attraction of $\mathrm{T}$ cells towards tumor in each CRC patient for individualized therapy.

\section{Conclusions}

Our study demonstrates the role of CCR2 and CCL2 in migration of CTLs towards tumor. Data obtained from additional CRC patients further strengthen the role of CCR2 and CCL2 in lymphocyte migration. Identification of chemokine/chemokine receptor pair responsible for attraction of $\mathrm{T}$ cells towards tumor in each patient will aid individualized therapy approaches using gene modification of tumor cells with chemokine or chemokine/ anti-tumor $\mathrm{Ab}$ fusion proteins to attract CTLs that potentially could inhibit tumor growth.

\section{Acknowledgements}

We thank James Hayden and Frederick Keeney for technical help on microscopy imaging and Jeffrey S. Faust, David Ambrose and Daniel Hussey for assistance in flow cytometry analyses. We thank Elsa Aglow and Russell Delgiacco for providing assistance in histotechnology. We also thank Drs. Yingtao Bi and Ramana Davuluri for statistical data analyses. This work is supported by National Institute of Health grants CA74294, and CA10815, by a grant from Corixa Corporation, by Intramural National Cancer Institute Funds, and by the Commonwealth Universal Research Enhancement program, Pennsylvania Department of Health.

\section{Author details}

${ }^{1}$ The Wistar Institute, 3601 Spruce Street, Philadelphia, PA 19104, USA Department of Medical Oncology, Thomas Jefferson University, 1015 Walnut Street, Philadelphia, PA 19107, USA. ${ }^{3}$ Department of Medical Oncology, Fox Chase Cancer Center, 333 Cottman Avenue, Philadelphia, PA 19111, USA. ${ }^{4}$ Division of Hematology and Oncology, University Hospitals Seidman Cancer Center and Case Western Reserve University, 11100 Euclid Avenue, Lakeside 1200, Cleveland, OH 44106-5065, USA.

\section{Authors' contributions}

KB carried out reconstruct studies and all the data analyses; PR carried out histological staining, RT-PCR of chemokines; TZ performed ELISA assays for chemokines; LG cultured and expanded CTLs for the assay, and characterized chemokine receptor expression on T cells; MM and NM recruited patients for the study, DH and RS designed the study and in coordination with all others drafted the manuscript. All authors read and approved the final version of the manuscript.

\section{Competing interests}

The authors declare that they have no competing interests.

Received: 15 September 2010 Accepted: 30 March 2011 Published: 30 March 2011

\section{References}

1. Somasundaram R, Herlyn D: Chemokines and the microenvironment in neuroectodermal tumor-host interaction. Semin Cancer Biol 2009, 19:92-96.

2. Luster AD: Chemokines-chemotactic cytokines that mediate inflammation. N Engl J Med 1998, 338:436-445.

3. Baggiolini M: Chemokines in pathology and medicine. J Intern Med 2001, 250:91-104.

4. Mackay CR: Chemokines: immunology's high impact factors. Nat Immunol 2001, 2:95-101.

5. Fridlender ZG, Buchlis G, Kapoor V, Cheng G, Sun J, Singhal S, Crisanti MC, Wang LC, Heitjan D, Snyder LA, Albelda SM: CCL2 blockade augments cancer immunotherapy. Cancer Res 70:109-118.

6. Payne AS, Cornelius LA: The role of chemokines in melanoma tumor growth and metastasis. J Invest Dermatol 2002, 118:915-922.
7. Raman D, Baugher PJ, Thu YM, Richmond A: Role of chemokines in tumor growth. Cancer Lett 2007, 256:137-165.

8. Ghadjar P, Rubie C, Aebersold DM, Keilholz U: The chemokine CCL20 and its receptor CCR6 in human malignancy with focus on colorectal cancer. Int J Cancer 2009, 125:741-745.

9. Akishima-Fukasawa Y, Nakanishi Y, Ino Y, Moriya Y, Kanai Y, Hirohashi S: Prognostic significance of CXCL12 expression in patients with colorectal carcinoma. Am J Clin Pathol 2009, 132:202-210, quiz 307.

10. Loberg RD, Ying C, Craig M, Day LL, Sargent E, Neeley C, Wojno K, Snyder LA, Yan L, Pienta KJ: Targeting CCL2 with systemic delivery of neutralizing antibodies induces prostate cancer tumor regression in vivo. Cancer Res 2007, 67:9417-9424.

11. Frederick MJ, Clayman GL: Chemokines in cancer. Expert Rev Mol Med 2001, 3:1-18.

12. Homey B, Muller A, Zlotnik A: Chemokines: agents for the immunotherapy of cancer? Nat Rev Immunol 2002, 2:175-184.

13. Vicari AP, Caux C: Chemokines in cancer. Cytokine Growth Factor Rev 2002, 13:143-154.

14. Erreni M, Bianchi P, Laghi L, Mirolo M, Fabbri M, Locati M, Mantovani A, Allavena P: Expression of chemokines and chemokine receptors in human colon cancer. Methods Enzymol 2009, 460:105-121.

15. Galon J, Costes A, Sanchez-Cabo F, Kirilovsky A, Mlecnik B, Lagorce-Pages C, Tosolini $M$, Camus $M$, Berger $A$, Wind $P$, Zinzindohoué $F$, Bruneval $P$, Cugnenc PH, Trajanoski Z, Fridman WH, Pagès F: Type, density, and location of immune cells within human colorectal tumors predict clinical outcome. Science 2006, 313:1960-1964.

16. Pages F, Berger A, Camus M, Sanchez-Cabo F, Costes A, Molidor R, Mlecnik B, Kirilovsky A, Nilsson M, Damotte D, Meatchi T, Bruneval P, Cugnenc PH, Trajanoski Z, Fridman WH, Galon J: Effector memory T cells, early metastasis, and survival in colorectal cancer. N Engl J Med 2005, 353:2654-2666.

17. Musha H, Ohtani H, Mizoi T, Kinouchi M, Nakayama T, Shiiba K, Miyagawa K, Nagura H, Yoshie O, Sasaki I: Selective infiltration of CCR5(+)CXCR3(+) T lymphocytes in human colorectal carcinoma. Int J Cancer 2005, 116:949-956.

18. Ohta M, Tanaka F, Yamaguchi $H$, Sadanaga $N$, Inoue $H$, Mori M: The high expression of Fractalkine results in a better prognosis for colorectal cancer patients. Int J Oncol 2005, 26:41-47.

19. Tosolini M, Kirilovsky A, Mlecnik B, Fredriksen T, Mauger S, Bindea G, Berger A, Bruneval P, Fridman WH, Pages F, Galon J: Clinical impact of different classes of infiltrating T cytotoxic and helper cells (Th1, th2, treg, th17) in patients with colorectal cancer. Cancer Res 71:1263-1271.

20. Baier PK, Eggstein S, Wolff-Vorbeck G, Baumgartner U, Hopt UT: Chemokines in human colorectal carcinoma. Anticancer Res 2005, 25:3581-3584.

21. Bailey C, Negus R, Morris A, Ziprin P, Goldin R, Allavena P, Peck D, Darzi A: Chemokine expression is associated with the accumulation of tumour associated macrophages (TAMs) and progression in human colorectal cancer. Clin Exp Metastasis 2007, 24:121-130.

22. Monti P, Leone BE, Marchesi F, Balzano G, Zerbi A, Scaltrini F, Pasquali C, Calori G, Pessi F, Sperti C, Di Carlo V, Allavena P, Piemonti L: The CC chemokine MCP-1/CCL2 in pancreatic cancer progression: regulation of expression and potential mechanisms of antimalignant activity. Cancer Res 2003, 63:7451-7461.

23. Nesbit M, Schaider H, Miller TH, Herlyn M: Low-level monocyte chemoattractant protein-1 stimulation of monocytes leads to tumor formation in nontumorigenic melanoma cells. J Immunol 2001, 166:6483-6490.

24. Huang S, Singh RK, Xie K, Gutman M, Berry KK, Bucana CD, Fidler IJ, Bar-Eli M: Expression of the JE/MCP-1 gene suppresses metastatic potential in murine colon carcinoma cells. Cancer Immunol Immunother 1994, 39:231-238.

25. Dranoff G: Cytokines in cancer pathogenesis and cancer therapy. Nat Rev Cancer 2004, 4:11-22

26. Braun SE, Chen K, Foster RG, Kim CH, Hromas R, Kaplan MH, Broxmeyer HE, Cornetta K: The CC chemokine CK beta-11/MIP-3 beta/ELC/Exodus 3 mediates tumor rejection of murine breast cancer cells through NK cells. $\mathrm{J}$ Immunol 2000, 164:4025-4031.

27. Fushimi T, O'Connor TP, Crystal RG: Adenoviral gene transfer of stromal cell-derived factor- 1 to murine tumors induces the accumulation of dendritic cells and suppresses tumor growth. Cancer Res 2006, 66:3513-3522. 
28. Sharma S, Stolina M, Luo J, Strieter RM, Burdick M, Zhu LX, Batra RK, Dubinett SM: Secondary lymphoid tissue chemokine mediates T celldependent antitumor responses in vivo. J Immunol 2000, 164:4558-4563.

29. Mitchell MS, Darrah D, Yeung D, Halpern S, Wallace A, Voland J, Jones V, Kan-Mitchell J: Phase I trial of adoptive immunotherapy with cytolytic T lymphocytes immunized against a tyrosinase epitope. J Clin Oncol 2002 20:1075-1086.

30. Buckanovich RJ, Facciabene A, Kim S, Benencia F, Sasaroli D, Balint K, Katsaros D, O'Brien-Jenkins A, Gimotty PA, Coukos G: Endothelin B receptor mediates the endothelial barrier to $T$ cell homing to tumors and disables immune therapy. Nat Med 2008, 14:28-36.

31. Penichet ML, Morrison SL: Antibody-cytokine fusion proteins for the therapy of cancer. J Immunol Methods 2001, 248:91-101.

32. Berencsi K, Meropol NJ, Hoffman JP, Sigurdson E, Giles L, Rani P, Somasundaram R, Zhang T, Kalabis J, Caputo L, Furth E, Swoboda R, Marincola F, Herlyn D: Colon carcinoma cells induce CXCL11-dependent migration of CXCR3-expressing cytotoxic T lymphocytes in organotypic culture. Cancer Immunol Immunother 2007, 56:359-370.

33. Somasundaram R, Jacob L, Swoboda R, Caputo L, Song H, Basak S, Monos D, Peritt D, Marincola F, Cai D, Birebent B, Bloome E, Kim J, Berencsi K, Mastrangelo M, Herlyn D: Inhibition of cytolytic T lymphocyte proliferation by autologous CD4+/CD25+ regulatory T cells in a colorectal carcinoma patient is mediated by transforming growth factorbeta. Cancer Res 2002, 62:5267-5272.

34. Zhang T, Somasundaram R, Berencsi K, Caputo L, Gimotty P, Rani P, Guerry D, Swoboda R, Herlyn D: Migration of cytotoxic T lymphocytes toward melanoma cells in three-dimensional organotypic culture is dependent on CCL2 and CCR4. Eur J Immunol 2006, 36:457-467.

35. Felgar RE, Furth EE, Wasik MA, Gluckman SJ, Salhany KE: Histiocytic necrotizing lymphadenitis (Kikuchi's disease): in situ end-labeling, immunohistochemical, and serologic evidence supporting cytotoxic lymphocyte-mediated apoptotic cell death. Mod Pathol 1997, 10:231-241.

36. Friedl P, Entschladen F, Conrad C, Niggemann B, Zanker KS: CD4+ T lymphocytes migrating in three-dimensional collagen lattices lack focal adhesions and utilize beta1 integrin-independent strategies for polarization, interaction with collagen fibers and locomotion. Eur $\mathrm{J}$ Immunol 1998, 28:2331-2343.

37. Rao WH, Hales JM, Camp RD: Potent costimulation of effector T lymphocytes by human collagen type I. J Immunol 2000, 165:4935-4940.

38. Aiba S, Nakagawa S, Hara M, Tomioka Y, Deguchi M, Tagami H: Cultured murine dermal cells can function like thymic nurse cells. J Invest Dermatol 1994, 103:162-167.

39. Murakami S, Okada H: Lymphocyte-fibroblast interactions. Crit Rev Oral Biol Med 1997, 8:40-50.

40. Crowston JG, Salmon M, Khaw PT, Akbar AN: T-lymphocyte-fibroblast interactions. Biochem Soc Trans 1997, 25:529-531.

41. Maas-Szabowski N, Stark HJ, Fusenig NE: Keratinocyte growth regulation in defined organotypic cultures through IL-1-induced keratinocyte growth factor expression in resting fibroblasts. J Invest Dermatol 2000, 114:1075-1084.

42. Maaser K, Wolf K, Klein CE, Niggemann B, Zanker KS, Brocker EB, Friedl P. Functional hierarchy of simultaneously expressed adhesion receptors: integrin alpha2beta1 but not CD44 mediates MV3 melanoma cell migration and matrix reorganization within three-dimensional hyaluronan-containing collagen matrices. Mol Biol Cell 1999, 10:3067-3079.

43. Binnerts ME, van Kooyk Y, Simmons DL, Figdor CG: Distinct binding of $T$ lymphocytes to ICAM-1, -2 or -3 upon activation of LFA-1. Eur J Immunol 1994, 24:2155-2160.

44. Zhang T, Somasundaram R, Berencsi K, Caputo L, Rani P, Guerry D, Furth E, Rollins BJ, Putt M, Gimotty P, Swoboda R, Herlyn M, Herlyn D: CXC chemokine ligand 12 (stromal cell-derived factor 1 alpha) and CXCR4dependent migration of CTLs toward melanoma cells in organotypic culture. J Immunol 2005, 174:5856-5863.

45. Starnes HF Jr: Biological effects and possible clinical applications of interleukin 1. Semin Hematol 1991, 28:34-41.

46. Rathmell JC, Farkash EA, Gao W, Thompson CB: IL-7 enhances the survival and maintains the size of naive T cells. J Immunol 2001, 167:6869-6876.

47. Wei WZ, Miller B, Gutierrez RM: Inhibition of tumor growth by peptide specific cytotoxic $T$ lymphocytes in a three-dimensional collagen matrix. J Immunol Methods 1997, 200:47-54.
48. Jacobs N, Moutschen MP, Franzen-Detrooz E, Boniver V, Boniver J, Delvenne P: Organotypic culture of HPV-transformed keratinocytes: a model for testing lymphocyte infiltration of (pre)neoplastic lesions of the uterine cervix. Virchows Arch 1998, 432:323-330.

49. Tasaki A, Yamanaka N, Kubo M, Matsumoto K, Kuroki H, Nakamura K, Nakahara C, Onishi H, Kuga H, Baba E, Tanaka M, Morisaki T, Katano M: Three-dimensional two-layer collagen matrix gel culture model for evaluating complex biological functions of monocyte-derived dendritic cells. J Immunol Methods 2004, 287:79-90.

50. Brown CE, Vishwanath RP, Aguilar B, Starr R, Najbauer J, Aboody KS, Jensen MC: Tumor-derived chemokine MCP-1/CCL2 is sufficient for mediating tumor tropism of adoptively transferred T cells. J Immunol 2007, 179:3332-3341.

51. Zibert A, Balzer S, Souquet M, Quang TH, Paris-Scholz C, Roskrow M, Dilloo D: CCL3/MIP-1alpha is a potent immunostimulator when coexpressed with interleukin-2 or granulocyte-macrophage colonystimulating factor in a leukemia/lymphoma vaccine. Hum Gene Ther 2004, 15:21-34.

52. Biragyn A, Tani K, Grimm MC, Weeks S, Kwak LW: Genetic fusion of chemokines to a self tumor antigen induces protective, T-cell dependent antitumor immunity. Nat Biotechnol 1999, 17:253-258.

53. Biragyn A, Kwak LW: Designer cancer vaccines are still in fashion. Nat Med 2000, 6:966-968.

54. Guidoboni M, Gafa R, Viel A, Doglioni C, Russo A, Santini A, Del Tin L, Macri E, Lanza G, Boiocchi M, Dolcetti R: Microsatellite instability and high content of activated cytotoxic lymphocytes identify colon cancer patients with a favorable prognosis. Am J Pathol 2001, 159:297-304.

55. Longo-Imedio MI, Longo N, Trevino I, Lazaro P, Sanchez-Mateos P: Clinical significance of CXCR3 and CXCR4 expression in primary melanoma. Int J Cancer 2005, 117:861-865.

56. Kim J, Mori T, Chen SL, Amersi FF, Martinez SR, Kuo C, Turner RR, Ye X, Bilchik AJ, Morton DL, Hoon DS: Chemokine receptor CXCR4 expression in patients with melanoma and colorectal cancer liver metastases and the association with disease outcome. Ann Surg 2006, 244:113-120.

57. Monteagudo C, Martin JM, Jorda E, Llombart-Bosch A: CXCR3 chemokine receptor immunoreactivity in primary cutaneous malignant melanoma: correlation with clinicopathological prognostic factors. J Clin Pathol 2007, 60:596-599.

58. Varney ML, Johansson SL, Singh RK: Distinct expression of CXCL8 and its receptors CXCR1 and CXCR2 and their association with vessel density and aggressiveness in malignant melanoma. Am J Clin Pathol 2006, 125:209-216.

doi:10.1186/1479-5876-9-33

Cite this article as: Berencsi et al:: In vitro migration of cytotoxic T lymphocyte derived from a colon carcinoma patient is dependent on CCL2 and CCR2. Journal of Translational Medicine 2011 9:33.

\section{Submit your next manuscript to BioMed Central and take full advantage of:}

- Convenient online submission

- Thorough peer review

- No space constraints or color figure charges

- Immediate publication on acceptance

- Inclusion in PubMed, CAS, Scopus and Google Scholar

- Research which is freely available for redistribution

Submit your manuscript at www.biomedcentral.com/submit
C Biomed Central 